\section{MODERN CAST IRON}

$\mathrm{F}_{\mathrm{r}}$ EW metallurgical products have shown such a marked improvement in quality during the last two decades as have the cast irons. So rapid has this advance been, that few, except those in immediate contact with the industry, can have kept abreast of the work done; and the engineer user has perforce lagged behind in his knowledge of the new materials thus placed at his disposal. It was presumably in appreciation of this fact that the Institution of Mechanical Engineers formed a Research Committee on High Duty Cast Irons for General Engineering Purposes, the first report of which was published in 1938. This was concerned with a general outline of the development of both the "high-duty" irons used on account of their enhanced strength, and of the special-duty irons employed in the main as a result of their possession of unusual physical or chemical properties.

On the outbreak of war, the attentions of the Committee were necessarily somewhat diverted to those matters within their province which would most immediately assist in the national effort. Of these, one of the most important was the question of making the fullest use of Great Britain's own iron ores, the most abundant of which are phosphoric. From these ores, irons containing up to around 1.5 per cent are produced, and the second report of the Committee, recently published by the Institution, is an excellent account, prepared by J. G. Pearce, director of the British Cast Iron Research Association, of the phosphoric grey irons used by the foundryman and engineer. The mechanical properties of these materials, both at ordinary and at elevated temperatures, are discussed, and curves are provided showing what type of properties may be expected from an iron of given carbon, silicon and phosphorus contents.

A third report, also prepared by $\mathrm{Mr}$. Pearce, is devoted to a consideration of the newest forms of alloyed irons. As a consequence of the War, a demand has arisen among engineers for fuller information regarding the special irons which are being used, both for their own sakes and as substitutes for other materials in urgent demand.

This report is divided into separate sections dealing respectively with the austenitic and the martensitic irons, and well fulfils its purpose. The former type of iron bears to ordinary ones a relationship not dissimilar from that borne by the stainless steels to plain carbon material. Their characteristic properties include softness, ductility, and high resistance to wear, erosion, corrosion and heat. In addition, they are non-magnetic, of high electrical resistance and thermal expansion and low thermal conductivity. These materials have passed far beyond the field of research, and an appendix contains a list of many scores of examples of typical applications of such irons in actual engineering practice.

Where resistance to wear or erosion is the factor of prime importance, the martensitic irons, on account of their great hardness, find many important uses, some sixty or seventy specific examples of which are cited.

These reports, of which others are promised, contain select but adequate references to original sources of information, and should be of great value to makers and users alike. The author, the Committee and the Institution, in preparing and publishing this information, are performing a service of immediate national importance.

\section{FORTHCOMING EVENTS}

\author{
MONDAY, NOVEMBER 17
}

ROYAL GEOGRAPHICAL SOCIETY (at Kensington Gore, London, S.W.7) at 3 p.m.-Miss L. E. Cheesman: "The Border Mountains and at, 3 p.m.-Miss L. E. Cheesman: "The , B

Royal Society of ARTs (at John Adam Street, Adelphi, London, W.C.2), at 1.45 p.m.-Mr. A. J. Curtin Cosbie: "Brewing, the Story of a National Industry" 1: Brewing Materials. (Cantor Lectures, I).

WEDNESDAY, NOVEMBER 19

Society of GLASs TECHNOLOGY (at Elmfield, Northumberland Road, Sheffield, 10). Twenty-fifth Anniversary Meeting. 10 a.m.-Symposium on Glass Furnace Problems, I. 2.35 p.m.-Symposium on Glass Furnace Problems, II.

THURSDAY, NOVEMBER 20

Chemical Society (at Burlington House, Piccadilly, London, W.1) at 2.30 p.m.-Dr. W. T. Astbury, F.R.S.: "X-Rays and the Stoichiochemistry of the Proteins".

ROXAL INSTITUTION OF GREAT BRITAIN (at 21 Albemarle street, London, W.1), at 2.30 p.m.- Sir James Jeans, O.M., F.R.S. : "Is there Life on Other Worlds ?'

FRIDAY, NOVEMBER 2

Institution of Mechanical Engineers (at Storey's Gate, St. James's Park, London, S.W.1), at 2.30 p.m.-Mr. W. T. Halcrow: "A Century of Tunnelling" (Thomas Hawksley Lecture).

\section{APPOINTMENTS VACANT}

APPLICATIONS are invited for the following appointments on or before the dates mentioned:

DIRECToR of EDucation-The Town Clerk and Clerk to the Local Education Authority, Town Hall, Brighouse, Yorks. (endorsed 'Director of Education') (November 19).

BoROUGH ANALYST-The Town Clerk, Town Hall, Burnley (November 24$)$.

Senior Assistant to the Principal of the Barrow-in-Furness Technical college and Junior Technical School (will be required to take Evening Classes in MEchANICAL ENGINwERING)-The Director of Education, Town Hall, Barrow-in-Furness (November 29).

\section{REPORTS AND OTHER PUBLICATIONS}

(not included in the monthly Books Supplement)

\section{Great Britain and Ireland}

Hull Bulletins of Marine Ecology. Vol. 1, Nos. 4 and 5 : Ecological Investigations with the Continuous Plankton Recorder-The Copepoda of the Southern North Sea, 1932-37, by K. M. Rae and J. H. Fraser Ecological Relations between the Herring and the Plankton of the North-East Coast of England, by C Cheng the Plankton off the 65-125. 108. Vol 2 Nos 7 and 8. Conting. Pp. 171-254+plate General Introduction to the 1938-39 Survey, by Dr. A. C. Hardy General Introduction to the 1938-39 Survey, by Dr. A. C. Hardy Continuous Plankton Records-Phytoplankton in the North Sea, Pp. 46 + plates 1-38. 8s. (Hull: University College.) W. Macnae).

\section{Other Countries}

U.S. Office of Education: Federal Security Agency. Vocational Division, Monograph No. 22: Farm-Family Living: contributing to Satisfying Farm-Family Living through Cooperative Educational Programs in Vocational Agriculture and Home Economics. Pp. iii +12 . (Washington, D.C. : Government Printing Office.) 5 cents. [2010 National Research Council of Canada. N.R.C. No. 1011: Abstracts on Storage of Grain. By Muriel E. Whalley. Pp. 180. (Ottawa: National Research Council of Canada.) 3 dollars. P. 180. (Ottawa:
[2210

New Zealand: State Forest Service. Annual Report of the Director of Forestry for the Year ended 31st March 1941. Pp. 50. (Wellington : Government Printer.) 1s. $3 d$.

New Zealand. Fifteenth Annual Report of the Department of Scientific and Industrial Research. Pp. 92. (Wellington: Government Printer.) 9d. $[2210$ Report on the Department of Agriculture, St. Lucia, 1940. Pp. ii +12. (St. Lucia: Government Printing Office.) 6d. ${ }_{\text {[2210 }}^{\text {Pp. }}$

Editorial and Publishing Offices
MACMILLAN \& CO., LTD.,
ST. MARTIN'S STREET, LONDON, W.C.2.
Telephone: Whitehail 883I Telegrams: Phusis Lesquare London
Advertisements should be addressed to
T. G. Scott \& Son, Ltd., Three Gables, London Road, Merstham, Surrey
Telephone : Merstham 316

The annual subscription rate is $£ 4100$, payable in advance, Inland or Abroad All rights reserved. Registered as a Newspaper at the General Post Office 